\title{
ТЕОРЕТИЧНІ I ПРАКТИЧНІ АСПЕКТИ АДМІНІСТРАТИВНО-ПРАВОВОГО РЕГУЛЮВАННЯ У СФЕРІ ЗАХИСТУ ПРАВ СПОЖИВАЧІВ В УКРАЇНI
}

\author{
ДОВГАНЬ Юлія Анатоліївна - здобувач кафедри адміністративного права \\ та процесу, фінансового та інформаційного права ПВНЗ «Львівський університет \\ бізнесу та права»
}

УДК 342.92

DOI 10.32782/EP.2021.12

Статья посвящена теоретическим и практическим проблемам административноправового регулирования в сбере обеспечения прав потребителей в Украине. Проанализированъ особенности административно-правового регулирования в сбере обеспечения прав потребителей и определенъ пути его совершенствования. Сформулированы предложения по совершенствованию правового регулирования в сбере обеспечения прав потребителей, оптимизации правового статуса субъектов соответствуюших правоотношений. Отмечено, что права потребителей представляют собой законодательно закрепленньий комплекс правовых возможностей человека и гражданина, основанный на соответствующих положениях Конституции Украинъи, связаннъий с удовлетворением разнообразных потребностей в товарах или услугах и направлен на обеспечение надлежащего уровня жизнедеятельности человека и его безопасности, реализацию и защиту соответствуюших прав и свобод.

Ключевъие слова: защита прав потребителей, административно-правовое регулирование, нормативно-правовой механизм государственного управления, приницпь государственного управления, обеспечения прав потребителей.

Постановка проблеми

Захист споживача належить до найбільш актуальних правових проблем сучасності, порівнюваних за своєю значущістю хіба що 3 охороною довкілля. Виникнення самої проблеми пояснюється двома причинами: з одного боку, зростання ролі споживання, попиту населення на товари та послуги, а 3 іншого погіршення становища споживача [1, с. 262]. У процесі ринкових перетворень, ускладнених такими явищами, як інфляція та підвищення цін, значно знизився рівень соціального захисту населення. Зростає кількість скарг споживачів на незадовільну якість продукції, надання послуг та обслуговування.

Недостатньо реалізується право споживача на отримання необхідної йому достовірної інформації про товари, роботи, послуги, а також права споживачів бути почутими, захищеними та одержати відшкодування збитків за завдану шкоду [2, с. 88].

Аналіз останніх досліджень

Проблеми правового захисту прав споживачів знайшли відображення в роботах таких дослідників, як: Т.О. Кагал, А.А. Мазаракі, А.В. Ніколаєва, О.М. Язвінська, Г.А. Осетинська, А.О. Ісічко, А.М. Іваненко, А.А. Микитенко та ін.

Виклад основного матеріалу

3 середини XX століття хоч і повільними темпами, але все-таки почали закладатися правові норми щодо регулювання питань захисту прав споживачів. Так, у 50 -х роках була започаткована практика розроблення та впровадження правил торгівлі за певними групами продовольчих і непродовольчих товарів. Ці правила передбачали норми та організаційно-правові заходи, які так 
чи інакше визначали особливий правовий статус покупців у роздрібній торгівлі, встановлювали відповідно до тодішніх суспільно-економічних обставин у країні деякі додаткові гарантії реалізації ними своїх прав. Це призводило до ситуації, коли права покупців визначалися не законом, а під законними нормативними актами, які ці правила нівелювали, адже кожна служба насамперед прагнула в цих актах належним чином захистити свої інтереси, не допустити встановлення для підприємств системи обтяжливих обов'язків перед покупцями [3].

1956 року Міністерство торгівлі СРСР затвердило «Правила обміну промислових товарів, придбаних у роздрібній торговельній мережі». Відповідно до згаданих правил, в разі виявлення у придбаному товарі дефектів, покупець мав право на безоплатне усунення недоліків від майстерень гарантійного ремонту, а якщо таких немає - від магазину.

1967 року замість цих правил Міністерство торгівлі СРСР ухвалило «Типові правила обміну промислових товарів, придбаних у роздрібній торговельній мережі», у яких визначено загальні положення про обмін промислових товарів, придбаних у державній і кооперативній роздрібній торговельній мережі.

Знаковою подією було прийняття 1963 року Цивільного кодексу УРСР, у ст. 234 якого містилася норма щодо права покупця, якому продана річ неналежної якості, якщо іiі недоліки не були зазначені продавцем, за своїм вибором вимагати або заміни речі належної якості, або пропорційного зменшення купівельної ціни, або безоплатного усунення недоліків речі продавцем чи відшкодування витрат покупця на їх виправлення, або розірвання договору з відшкодуванням покупцю збитків [3].

Важливе місце серед нормативно-правових актів у сфері торгівлі відводилось правилам торгівлі тими чи іншими продовольчими товарами, що затверджувались відповідними наказами Міністерства торгівлі СРСР (хлібом і хлібними виробами, плодоовочевими товарами, алкогольними напоями, молочними продуктами). Однак вони практично не встановлювали порядку здійснення покупцями прав у разі придбання продовольчих товарів неналежної якості, а переважно містили положення щодо врегулювання відносин з організації торгівлі, встановлення відповідних санітарних вимог до зберігання продовольчих товарів тощо.

Загалом Правила обміну промислових товарів містили положення, які обмежували права покупців, визначені цивільним законодавством, істотно знижували ступінь їх правової захищеності. Так, покупець, який придбав товар неналежної якості щодо якого встановлено гарантійний термін, насамперед повинен був звертатися 3 вимогою про його ремонт. I лише тоді, коли відремонтовані товари потребували другого чи третього ремонту (залежно від виду товару i складності ремонту) або взагалі не могли бути відремонтовані протягом встановленого часу, покупець мав право обміняти неякісні вироби на інші тієї самої марки 3 відповідним перерахунком грошової суми або вимагати повернення суми, сплаченої ним під час укладення договору. Тому громадяни (покупці) змушені були насамперед звертатися 3 вимогами про ремонт неякісних виробів до підприємств-виготовлювачів товарів або до спеціальних гарантійних майстерень, які могли за власним розсудом кваліфікувати складність ремонту та походження поломки виробу таким чином, щоб не допустити його обміну на якісний виріб або уникнути повернення суми його купівельної вартості [3].

Внаслідок цих та інших штучно створюваних перешкод громадяни досить часто були позбавлені можливості користуватися придбаними ними речами, а торговельні підприємства практично не несли майнової відповідальності перед покупцями за продаж неякісних товарів.

За Правилами обміну промислових товарів покупцеві, який виявив явні недоліки в куплених товарах, щодо яких не встановлено гарантійних строків (одяг, тканини, хутро, килими тощо), надавалося право за своїм вибором обміняти цей товар за місцем придбання лише протягом 14 днів або отримати грошову суму за повернену річ. При виявленні у купленій речі прихованих недоліків, підтверджених лабораторними 
дослідженнями, покупець мав право на іï обмін у магазині протягом шести місяців 3 дня купівлі. Отже, реалізація покупцями в таких випадках своїх прав була поставлена в залежність від характеру недоліків (явних чи прихованих), що не узгоджувалося з цивільним законодавством. Не передбачалося правилами право покупця на відшкодування збитків, завданих йому внаслідок придбання речі з недоліками.

Правилами обміну промислових товарів покупцеві надавалося право лише обміняти товар належної якості на аналогічний товар (щодо якого не встановлено гарантійних строків), якщо куплений товар не підійшов йому за формою, фасоном, кольором, розміром. Розірвання договору з поверненням товару, а покупцеві його купівельної вартості можливе було тільки за згодою продавця.У переважній більшості країн світу законодавство про захист прав споживачів або повністю базується, або значною мірою враховує основний міжнародно-правовий документ у цій сфері - підготовлені Економічною і соціальною радою ООН «Керівні принципи для захисту інтересів споживачів», схвалені Генеральною Асамблеєю ООН 9 квітня 1985 року (резолюція № 39/248).

Відповідно до цієї резолюції, країни-члени ООН зобов'язались, зокрема й Україна, проводити активну політику щодо захисту прав споживачів з урахуванням вищезазначених керівних принципів.

Законодавство 3 питань захисту прав споживачів в Україні почало розроблятись наприкінці 80-х, початку 90-х років, в умовах, коли у державі було ліквідовано відповідні органи управління, органи відомчого та міжвідомчого контролю у сфері обслуговування населення.

Україна, першою з усіх країн СНД прийняла Закон «Про захист прав споживачів», чим засвідчила перед усім світом свою повагу до міжнародних засад цивілізованого захисту громадян як споживачів [4].

Закон «Про захист прав споживачів» від 12.05.1991р. став підставою для прийняття низки підзаконних актів Кабінету Міністрів України, міністерств та державних комітетів, що стосуються захисту прав споживачів. Законом було вперше чітко регламентовано порядок реалізації споживачем прав у разі придбання товару, отримання послуг неналежної та належної якості [5, с. 10].

Закон передбачав право покупця вибирати дії у випадку купівлі товару чи надання послуги неналежної якості: чи розірвання договору і повернення коштів, чи усунення, виправлення недоліків речі продавцем або самим покупцем, але за рахунок підприємця. Отже, є підстави вважати, що законодавство про захист прав споживачів стало прогресивнішим порівняно 3 тим, що діяло раніше, попри його певну незавершеність i недосконалість.

Уже у середині 1992 р. стало зрозуміло, що Закон України «Про захист прав споживачів» 1991 р. не відповідає вимогам часу і його було суттєво доопрацьовано.

Закон України «Про внесення змін та доповнень до Закону Української РСР «Про захист прав споживачів», який було прийнято 15 грудня 1993 р., віддзеркалював ті кардинальні зміни, що відбулися в Україні за період з дня ухвалення першої редакції закону щодо захисту прав споживачів. Так, у серпні 1991 р. Україна стала незалежною державою, і це змінило багато акцентів політичного, економічного і соціального життя в країні. Головне, що закон 1993 р. уже містив у собі систему контролю за якістю товарів народного споживання, додержання правил торгівлі та надання послуг, а також норми адміністративної відповідальності, що настає при порушенні прав споживачів. Зокрема, були заповнені окремі прогалини в регулюванні відносин за участю споживачів-громадян тощо [1, с. 265].

Зазначений закон розроблено i прийнято у контексті з принципами розбудови незалежної правової держави, а також 3 Керівними принципами для захисту інтересів споживачів. Керуючись нормами статей Закону «Про захист прав споживачів» Уряд України затвердив відповідні правила, порядки тощо у сфері обслуговування громадян. На цей час закон діє у редакції від 1 грудня 2005 року [4].

Сьогодні нормативно-правова база консумеризму в Україні нараховує більше 100 законів та підзаконних нормативних актів, 


\section{Адміністративне право}

ухвалених для захисту прав громадян як споживачів.

Насамперед варто зазначити, що права споживачів захищає Конституція України, прийнята 28 червня 1996 р., стаття 42 якої проголошує: “Держава захищає права споживачів, здійснює контроль за якістю і безпечністю продукції та усіх видів послуг і робіт, сприяе діяльності громадських організацій споживачів». А в частині 1 статті 50 Конституції закріплено право громадян на вільний доступ до інформації про стан довкілля, про якість харчових продуктів та предметів побуту. Стаття 22 містить досить важливе положення про те, що конституційні права і свободи гарантуються і не можуть бути скасовані, не допускається звуження змісту та обсягу існуючих прав тощо. Безумовно, що це все стосується і захисту прав споживачів [6].

Особливого значення в системі законодавства України про захист прав споживачів набувають норми Цивільного, Цивільно-процесуального, Кримінального, Кримінально-процесуального, Кодексу України про адміністративні правопорушення та інших нормативних актів [7,8].

Прийняття у 2003 році нового Цивільного кодексу України (далі - ЦК) було значним поступом у правовому регулюванні захисту прав споживачів. Зокрема, у ньому окремо врегульовані відносини, що виникають у зв'язку з укладенням договору роздрібної купівлі-продажу між споживачами та підприємцями. Цей договір є публічним, тобто покупцем стає кожна особа, яка звернеться за товаром, умови договору є зразковими, споживач односторонньо не може їх змінити, він може лише погодитися на них або відмовитися від укладення договору взагалі. Відповідно до статті 700 ЦК, на продавця покладено обов'язок надати покупцеві необхідну й достовірну інформацію про товар, що пропонується до продажу. Однак слід зазначити, що багато норм, включених у ЦК, повторюють положення Закону України «Про захист прав споживачів», відповідно до змін від 10 січня 2002 року, зокрема, щодо відшкодування збитків за продаж неякісної продукції.
Важливо зазначити, що в новому ЦК України було визначено особливості договорів купівлі-продажу з умовою про прийняття покупцем товару у встановлений строк (ст. 703), за зразками (ст. 704), з використанням автоматів (ст. 705), з умовою про доставку товару покупцеві (ст. 706) і відповідно встановлено порядок їх укладення та використання.

Стаття 227 Кримінального кодексу передбачає, що за випуск на товарний ринок або інша реалізація споживачам недоброякісної, тобто такої, що не відповідає встановленим стандартам, нормам, правилам i технічним умовам, або некомплектної продукції і товарів, здійснені відповідальними за це особами, вчинені протягом року після накладення адміністративного стягнення за такі ж порушення, караються штрафом від трьох до п’ятисот мінімальних розмірів заробітної плати. А за ті ж дії, якщо вони вчинені у великих розмірах або завдали шкоди здоров'ю чи призвели до смерті споживача, караються позбавленням волі на строк до п’яти років [7].

1 грудня 2005 року Верховна Рада України прийняла підготовлений Кабінетом Міністрів України Закон України «Про внесення змін до Закону України «Про захист прав споживачів» (у новій редакції). Метою Закону є приведення законодавства України у відповідність до вимог європейського законодавства щодо захисту прав споживачів, забезпечення безпечності продукції в процесі іiі розповсюдження та розміщення на ринку.

Прийнятий Закон реалізував завдання щодо адаптації Закону України «Про захист прав споживачів» до 9-ти директив Европейського Союзу:

Парламенту та Ради 97/7 EЕC від 20 травня 1997 року про угоди, які укладено на відстані;

Ради 85/577 ЕЕС від 20 грудня 1985 року про продаж поза діловими приміщеннями;

Ради 93/13 EЕС від 5 квітня 1993 року про несправедливі умови в контрактах зі споживачами;

Ради 98/6 EC від 16 лютого 1998 року про захист прав споживачів при встанов- 
ленні ціни на товари, що пропонуються споживачам;

Ради 99/44 EC від 25 травня 1999 року про деякі особливості продажу споживчих товарів і пов'язаних з ними гарантій;

Ради 85/374 EЕС від 25 липня 1985 року щодо зближення законів, підзаконних $\mathrm{i}$ адміністративних актів держав-членів стосовно відповідальності за неякісну продукцію;

Ради 87/102/EЕС від 22 грудня 1986 року щодо наближення законів, підзаконних і адміністративних положень держав - членів щодо споживчого кредиту;

Ради 84/450/EEC від 10 вересня 1984 року стосовно реклами, що вводить в оману, таким чином, що ії дія поширюється також на порівняльну рекламу;

Ради 98/27 СС від 19 травня 1998 року щодо судових заборон з метою захисту прав споживачів [3].

Зазначимо, що в Україні, так само, як і в $\mathrm{EC}$, сьогодні розвинена нормативно-правова база у сфері захисту прав споживачів, але проблема захисту цих прав не вирішена. Негативними чинниками залишаються: підробка товарів, неконтрольований ринок, недостовірна реклама, неякісні товари і послуги, проблема відшкодування збитків тощо. Тому нормативно-правова база України у цій сфері потребує подальшого вдосконалення [2, с. 91].

Метою реалізації споживчої політики $\mathrm{EC}$ визначено стабільний розвиток внутрішнього ринку $\mathrm{EC}$ та поточний вплив Европейської Комісії на повсякденне життя громадян EC, який здійснюється шляхом забезпечення пріоритетності потреб споживачів.

21 березня 2014 року у Брюсселі було підписано політичну частину Угоди про асоціацію з EC за участі українського прем'єрміністра Арсенія Яценюка.

27 червня 2014 року - Президент України Петро Порошенко підписав другу (економічну) частину Угоди про асоціацію 3 EC.

16 вересня 2014 року Европейський парламент ратифікував Угоду про асоціацію між Україною і Європейським Союзом синхронно з Верховною Радою України (у вигляді телемосту технологією Skype).
31 листопада 2014 р. вступило в силу тимчасове застосування Угоди про Асоціацію.

23 лютого 2017 Верховна Рада ратифікувала Угоду між Урядом України і Eвропейським Союзом про участь України у програмі COSME. Підписавши Угоду про асоціацію між Україною, з одного боку, та Європейським Союзом, Европейським співтовариством 3 атомної енергії і іхніми державами-членами, з іншого боку, ратифіковану Верховною Радою України у вересні 2014 року (далі - Угода про асоціацію), Україна взяла на себе зобов'язання забезпечити високий рівень захисту прав споживачів та досягти сумісності між системами захисту прав споживачів України та EC.

29 березня 2017 р. № 217-р схвалено концепцію державної політики у сфері захисту прав споживачів на період до 2020 року, метою цієї Концепції є створення та впровадження ефективної системи захисту прав споживачів в Україні на засадах EC 3 урахуванням кращих практик країн EC.

Загалом, політика України та Европейського Союзу у сфері захисту прав споживачів спрямована на зменшення нерівності між споживачами та продавцями, підвищення рівня безпеки та здоров’я людей, покращення стандартів життя.

Основними завданнями Концепції є:

- гармонізація системи захисту прав споживачів в Україні з принципами, підходами та практиками $\mathrm{EC}$;

- адаптація у повному обсязі національного законодавства 3 питань захисту прав споживачів до законодавства $\mathrm{EC} \mathrm{відпо-}$ відно до зобов'язань України, передбачених Угодою про асоціацію;

- забезпечення конституційних гарантій безпеки та якості споживання, в тому числі шляхом унеможливлення зниження досягнутого рівня захисту прав споживачів;

- створення умов для впровадження та розвитку споживчої освіти всіх рівнів, підвищення рівня споживчої грамотності;

- забезпечення впровадження прозорих та ефективних механізмів взаємодії державних органів, органів місцевого самоврядування, громадських об'єднань спо- 
живачів, представників бізнесу у сфері здійснення захисту прав споживачів;

- удосконалення інформації для споживачів про товари та послуги на споживчому ринку, яка повинна бути доступною, об'єктивною, достовірною та своєчасно наданою, у тому числі інформація, що надається з використанням Інтернету, для попередження про потенційні ризики і небезпеку споживання;

- забезпечення прозорості зворотного зв'язку між споживачами та всіма органами виконавчої влади щодо звернень і скарг споживачів, компенсації шкоди, завданої споживачам у разі порушення їх прав [9].

Законодавство щодо захисту прав споживачів складається також 3 низки нормативно-правових актів різних рівнів. Це - закони України «Про рекламу» від 3 липня 1996 р. № 270, «Про метрологію та метрологічну діяльність» від 1 лютого 1998 р.№ 113, «Про стандартизацію» від 17 травня 2001 р. № 2408, «Про підтвердження відповідності» від 17 травня 2001 р. № 2406, «Про державне регулювання виробництва і обігу спирту етилового, коньячного і плодового, алкогольних напоїв та тютюнових виробів» від 19 грудня 1995 р. № 481, декрети Кабінету Міністрів України «Про державний нагляд за додержанням стандартів, норм і правил і відповідальність за їх порушення» від 8 квітня 1993 р. № 30 та ін.

Захист прав споживачів у сфері торгівлі забезпечуються відповідними положеннями законів України «Про забезпечення санітарного та епідеміологічного благополуччя населення», «Про пестициди і агрохімікати», «Про застосування реєстраторів розрахункових операцій у сфері торгівлі, громадського харчування та послуг», «Про лікарські засоби», «Про безпечність та якість харчових продуктів», «Про вилучення з обігу, перероблення, утилізацію, знищення або подальше використання неякісної та небезпечної продукції», «Про розповсюдження примірників аудіовізуальних творів та фонограм».

Окрему групу актів законодавства становлять закони України, які регулюють відносини за участю споживачів у відповідних сферах життєдіяльності. До таких актів можна віднести закони України «Про туризм» від 15 вересня 1995 р. № 324, «Про страхування» від 7 березня 1996 р.№ 85, «Про телекомунікації» від 18 листопада 2003 р. № 1280 та ін. Зазначені закони базуються на основних вимогах Закону України «Про захист прав споживачів» [4].

Значну роль щодо захисту прав споживачів виконують підзаконні нормативноправові акти - рішення Кабінету Міністрів України. До основних таких підзаконних актів належать постанови Кабінету Міністрів України від 15 червня 2006 р. № 833 «Порядок провадження торговельної діяльності і правила торговельного обслуговування населення» та від 16 травня 1994 р.№ 313 «Правила побутового обслуговування населення» (із змінами та доповненнями).

Принцип захисту прав споживачів від проявів несумлінної конкуренції та монополізму у будь-яких сферах підприємництва реалізовується у Господарському кодексі України, відповідних положеннях законів України, «Про захист від недобросовісної конкуренції» та «Про природні монополії», а також «Про захист економічної конкуренції».

Особливу категорію складають закони, що забезпечують право споживача на отримання якісної інформації (у тому числі про товари (роботи, послуги). До них, зокрема, належать закони України: «Про інформацію», «Про друковані засоби інформації (пресу) в Україні», «Про науково-технічну інформацію», «Про телебачення і радіомовлення», «Про рекламу» та «Про видавничу справу» [3].

Підстави та процедура притягнення до відповідальності за порушення законодавства про захист прав споживачів також закріплені в документах законодавчого органу влади: Законі України «Про захист прав споживачів», Цивільному кодексі України, Цивільно-процесуальному кодексі України, Кодексі України про адміністративні правопорушення, Кримінальному кодексі України та інших нормативних актах.

\section{Висновки}

Отже, на сьогодні в Україні створено законодавчу базу в сфері захисту прав споживачів, що потребує належних механізмів 


\begin{tabular}{|c|}
\hline 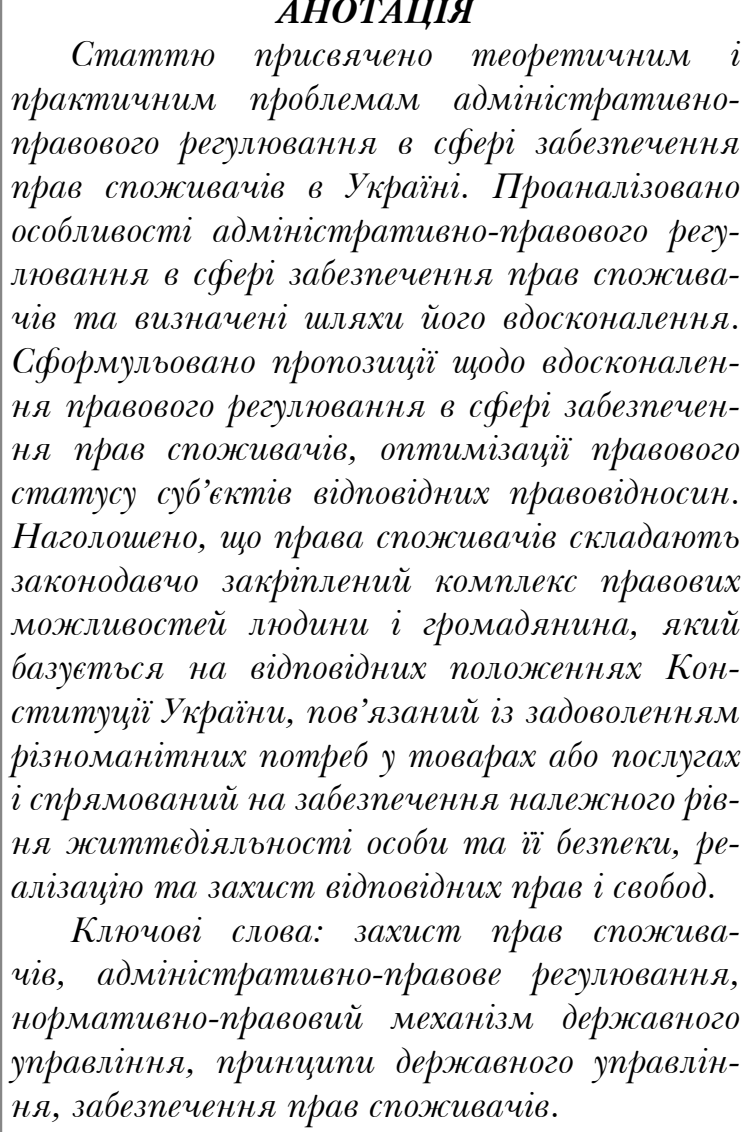 \\
\hline
\end{tabular}

iii застосування та реалізації, зокрема в частині гарантування якості окремих товарів, процедури реалізації споживачами їх прав на обмін товару неналежної якості та повернення коштів, можливості проведення незалежної експертизи проданих товарів та наданих послуг тощо.

\section{入iтература}

1. Коршакова О.В. Становлення законодавства щодо захисту прав споживачів в Україні. Право і безпека. 2012. 1 (43). С. 261-266.

2. Плахтій Ю, Байцар Р. Нормативноправове забезпечення у сфері захисту прав споживачів. Вимірювальна техніка та метрологія. № 74. 2013. С. 88-91.

3. http://cpk.org.ua/index.php?option $=$ com content\&view $=$ article\&id $=278$.

\section{SUMMARY}

The article is devoted to theoretical and practical problems of administrative and legal regulation in the field of consumer rights protection in Ukraine. The peculiarities of administrative and legal regulation in the field of consumer rights protection are analyzed and ways of its improvement are determined. A recommendation is made on proposals to improve legal regulation in the field of consumer rights protection, optimization of legal status of subjects of relevant legal relations. It is emphasized that consumer rights are a legally fixed set of legal possibilities of a person and a citizen based on the relevant provisions of the Constitution of Ukraine, related to the satisfaction of various needs in goods or services and is aimed at ensuring the proper level of human life and safety, implementation and protection Relevant rights and freedoms.

Key words: protection of consumer rights, administrative law regulation, normative-legal mechanism of state administration, principles of state administration, provision of consumer rights.

4. Про захист прав споживачів: Закон України № 1024-XII від 12.05.1991 р. URL: http://zakon4.rada.gov.ua/laws/show/102312

5. Зверева О.В. Захист прав споживачів. Навчальний посібник. К.: Центр учбової літератури, 2007. 192 с.

6. Конституція України: Прийнята на п’ятій сесії Верховної Ради України 28 червня 1996 р. Відомості Верховної Ради України. 1996. № 30 .

7. Кримінальний кодекс України від 05.04.2001 № 2341-III (BВP) 2001 № 2526. Ст. 131.

8. Цивільний кодекс України від 16 січня 2003p. № 435. URL: http://zakon2.rada. gov.ua.

9. Концепція державної політики у сфері захисту прав споживачів на період до 2020 року від 29 березня 2017 р. № 217-р. URL: http://zakon2.rada.gov.ua. 